\title{
Differential effects of adult mussels on the retention and fine-scale distribution of juvenile seed mussels and biofouling organisms in long-line aquaculture
}

\author{
Paul M. South ${ }^{1,2, *}$, Oliver Floerl ${ }^{1}$, Andrew G. Jeffs ${ }^{2}$ \\ ${ }^{1}$ Cawthron Institute, 98 Halifax Street East, Nelson 7010, New Zealand \\ ${ }^{2}$ Institute of Marine Science, University of Auckland, Private bag 92019, Auckland, New Zealand
}

\begin{abstract}
The majority of juvenile seed mussels are lost in aquaculture production. Understanding the causes of the losses of seed mussels is critical to reducing uncertainties in mussel aquaculture production. One major cause of loss appears to be the secondary settlement behaviour of mussels, which is thought to be a behavioural process by which larger juveniles can safely recruit among adults. This implies that once a juvenile mussel has settled among adults, there is either some impetus to remain or other positive interactions that promote increased survival. In this study, 2 densities ( 5 and 20 per $45 \mathrm{~cm}$ experimental rope) of adult green-lipped mussels Perna canaliculus were deployed alongside juvenile seed mussels to test whether this enhanced the retention of the juveniles in a typical suspended culture. Adult shells were also deployed to ascertain whether any effects were due to the physical presence of the mussels or the influence of their biological functioning. The presence of adult mussels or shells did not increase the retention of juvenile $P$. canaliculus, but small-scale movements of juveniles were increased by the addition of 20 live adult mussels per experimental rope. However, the presence of adult mussels and mussel shells on experimental ropes greatly increased the abundance of biofouling organisms. While the addition of live adult mussels or shells failed to provide a simple tool for increasing retention of seed mussels on aquaculture lines, they offer new insights into the identity and ecology of key biofouling organisms that can be problematic in mussel aquaculture production.
\end{abstract}

KEY WORDS: Mussel retention · Secondary settlement · Green-lipped mussel · Perna canaliculus · Mytilus galloprovincialis $\cdot$ Recruitment

\section{INTRODUCTION}

Increases in the global human population and its pressure on wild stocks of fish and shellfish have resulted in the rapid emergence of aquaculture to meet our growing demand for seafood (Naylor et al. 2000, Pauly et al. 2002). Mussel aquaculture has grown to become a major global industry during the last 30 yr (Smaal 2002, Carrasco et al. 2014, FAO 2016). The majority of mussel aquaculture relies on wild sources of larval and juvenile mussels to seed aquaculture substrata (e.g. ropes, rafts and benthic

${ }^{*}$ Corresponding author: paul.south@cawthron.org.nz mussel beds) in coastal production facilities. However, natural settlement of mussels is variable in space and time, and this variability causes considerable uncertainty in the continuity of aquaculture production (Carrasco et al. 2014). Access to wild seed sources for aquaculture is also increasingly being constrained by regulations such as quota allocation and reduced or managed access to seed-catching areas and seasons (de Vooys 1999, Smaal 2002). The early stages of mussel aquaculture production can be extremely inefficient, with massive quantities of juveniles frequently lost soon after capture, further

() The authors 2017. Open Access under Creative Commons by Attribution Licence. Use, distribution and reproduction are unrestricted. Authors and original publication must be credited. 
compounding the vulnerability of aquaculture operations to natural population fluctuations (Peteiro et al. 2007, Capelle et al. 2014). Retaining juvenile mussels within aquaculture production systems in the face of a natural tendency for losses is commonly referred to as 'retention'. Increasing the retention of juvenile seed mussels in the early production cycle would greatly increase the overall efficiency of the mussel aquaculture industry and lessen its susceptibility to natural variations in larval supply and settlement.

The New Zealand mussel industry is based on the aquaculture of the endemic green-lipped mussel Perna canaliculus (Gmelin, 1791) and has grown to an annual production of $101311 \mathrm{t}$ since its development in the 1970s (Aquaculture New Zealand 2016). The issue of retention has received particular attention in New Zealand, where the mussel aquaculture industry is almost entirely reliant on 1 ephemeral wild source of seed mussels (Alfaro \& Jeffs 2003, Alfaro et al. 2010). In recent years, overall production has been severely impacted by intermittent periods of limited availability of wild mussel seed. Furthermore, the retention of juvenile $P$. canaliculus on aquaculture growing substrata, such as fibrous nursery ropes, can be very poor, with losses that range from 50 to $100 \%$ (Jeffs et al. 1999, Webb \& Heasman 2006, Hayden \& Woods 2011). Consequently, a few studies have specifically addressed the causes of low retention, focussing on methods of determining the quality of juveniles captured from the wild (Webb \& Heasman 2006, Sim-Smith \& Jeffs 2011), impacts on fitness and behaviour that can occur during transport or due to poor handling (Webb \& Heasman 2006, Carton et al. 2007) and environmental conditions during early production (Alfaro 2006c, Carton et al. 2007, Hayden \& Woods 2011). However, the issue of retention is complex and far from understood, largely due to the small number of studies that have addressed this problem.

One of the most important factors governing the retention of $P$. canaliculus is likely to be the secondary settlement behaviour that is a pronounced feature of this species. Secondary settlement has been observed in $P$. canaliculus juveniles of $0.3-6 \mathrm{~mm}$ in length (Buchanan \& Babcock 1997, Jeffs et al. 1999, Hayden \& Woods 2011). Primary settlement occurs when mussel larvae of 240-300 $\mu \mathrm{m}$ transition from pelagic to benthic modes of life and undergo metamorphosis. Mussel larvae often initially settle on filamentous structures, such as algae, and this has been proposed as a mechanism to avoid consumption by, or competition with, conspecific adults, although there is supporting (Bayne 1964, Alfaro 2006a) and refuting (Lasiak \& Barnard 1995, Erlandsson et al. 2008) evidence for this being advantageous. Secondary settlement is the process by which juvenile mussels detach and migrate away from their initial larval settlement sites to explore, select and re-settle in alternative locations (Bayne 1964). Movement can occur via the juvenile initiating mucus drifting or pedal crawling behaviours that operate over medium $(10 \mathrm{~s}$ to $100 \mathrm{~s} \mathrm{~m})$ and small $(\mathrm{cm})$ scales, respectively (Bayne 1964, Buchanan \& Babcock 1997, Carton et al. 2007, Le Corre et al. 2013, South 2016). The ability of large numbers of juvenile mussels to migrate away from aquaculture growing structures is enormously problematic not only because these mussels are lost from the production cycle, but also because it creates vacant space for colonisation by biofouling organisms which can compete with the remaining cultured mussels and create problems for subsequent aquaculture processing (Fitridge et al. 2012). Furthermore, small-scale movements of juvenile mussels are of particular interest in New Zealand because seed mussels are usually attached to degradable substrata (e.g. algae or, in the case of hatchery-reared juveniles, coir ropes) when they are deployed at farm sites for on-growing. Therefore, it is essential that seed mussels migrate to permanent substrata (i.e. suspended growing ropes) if they are to remain in production.

The triggers of secondary settlement behaviour in juvenile mussels are not well understood and currently cannot be managed. There appear to be many potential triggers of secondary settlement processes in mytilid mussels, including changes in the local environment (Carton et al. 2007, Hayden \& Woods 2011) and changing habitat requirements or behaviour (Alfaro \& Jeffs 2002, Alfaro et al. 2004, von der Meden et al. 2010). Furthermore, juvenile seed mussels on growing structures will likely experience intense pressure from the ongoing settlement of a wide range of biofouling organisms competing for the same space (Holthuis et al. 2015). While biofouling organisms are known to impact the later stages of mussel aquaculture production, their effect on the retention of juveniles has not been examined in any detail.

One potential cause of secondary settlement migration is the proximity of the juvenile mussels to populations of conspecific adults. In natural habitats, mussels either settle as larvae directly among adults (Lasiak \& Barnard 1995, Dobretsov \& Wahl 2001) or arrive as secondary settlers following dispersal from primary settlement sites (Bayne 1964, Alfaro 2006b, Newell et al. 2010). Behavioural responses to physi- 
cal and chemical properties of the substratum can be important determinants of secondary settlement location in mussels (Alfaro et al. 2004, von der Meden et al. 2010). For example, juvenile Perna perna actively seek out adult conspecifics over small (cm) scales (Cáceres-Martínez et al. 1994, Erlandsson et al. 2008, Porri et al. 2016). The mechanisms used by juveniles to remotely locate adult mussels is unknown, but is likely to be a waterborne chemical cue, as has been observed for the primary larval settlement in a range of invertebrates, including mussels (Anderson 1996, Steinberg et al. 2002, de Vooys 2003, Alfaro et al. 2006, Morello \& Yund 2016). It is possible that as the juvenile mussels grow, their affinities for odours or surficial features shift to those associated with adults and therefore trigger secondary settlement (Bayne 1964, von der Meden et al. 2010). Determining whether this is the case could be of tremendous relevance for the development of approaches for reducing the losses of mussel juveniles in aquaculture operations.

If juvenile mussels undergo secondary settlement in order to recruit among adults, then it is possible that contact or close proximity to adult mussels might suppress secondary settlement behaviour. For example, juvenile $P$. canaliculus $>2 \mathrm{~mm}$ have been shown to secondarily settle into adult beds and recruit to the adult population (Alfaro 2006b). In addition, adult mussels can provide a structural refuge from predators and abiotic stressors to reduce post-settlement mortality (Bertness \& Grosholz 1985). If the presence of adult mussels suppresses secondary settlement of juveniles by providing chemical cues or physical refuge, then seeding adult individuals alongside conspecific juveniles for on-growing might offer an opportunity to reduce the losses of juveniles currently observed in many mussel farming operations.

This study used a field experiment to test whether deploying conspecific adults with juvenile seed mussels increases the retention of juveniles. In addition, small-scale movements of seed mussels were assessed to consider how the addition of adults might affect the distribution of seed mussels on nursery structures typically used in aquaculture production. The development of the biofouling assemblages was also described to gain a better understanding of which organisms might be problematic for mussel seed during the early stages of production.

\section{MATERIALS AND METHODS}

\section{Study site and source of juvenile mussels}

This study was undertaken on a long-line mussel farm operated by Sanford Ltd in outer Pelorus Sound in the Marlborough Sounds, New Zealand $\left(40^{\circ} 57^{\prime} 18^{\prime \prime} \mathrm{S}, 174^{\circ} 3^{\prime} 39^{\prime \prime} \mathrm{E}\right.$, Fig. 1). The juvenile mussels used in this study were hatchery-reared by SpatNZ Ltd (Nelson, New Zealand). Hatchery-reared juveniles within a single cohort have consistently shared developmental histories, such as shared pa-

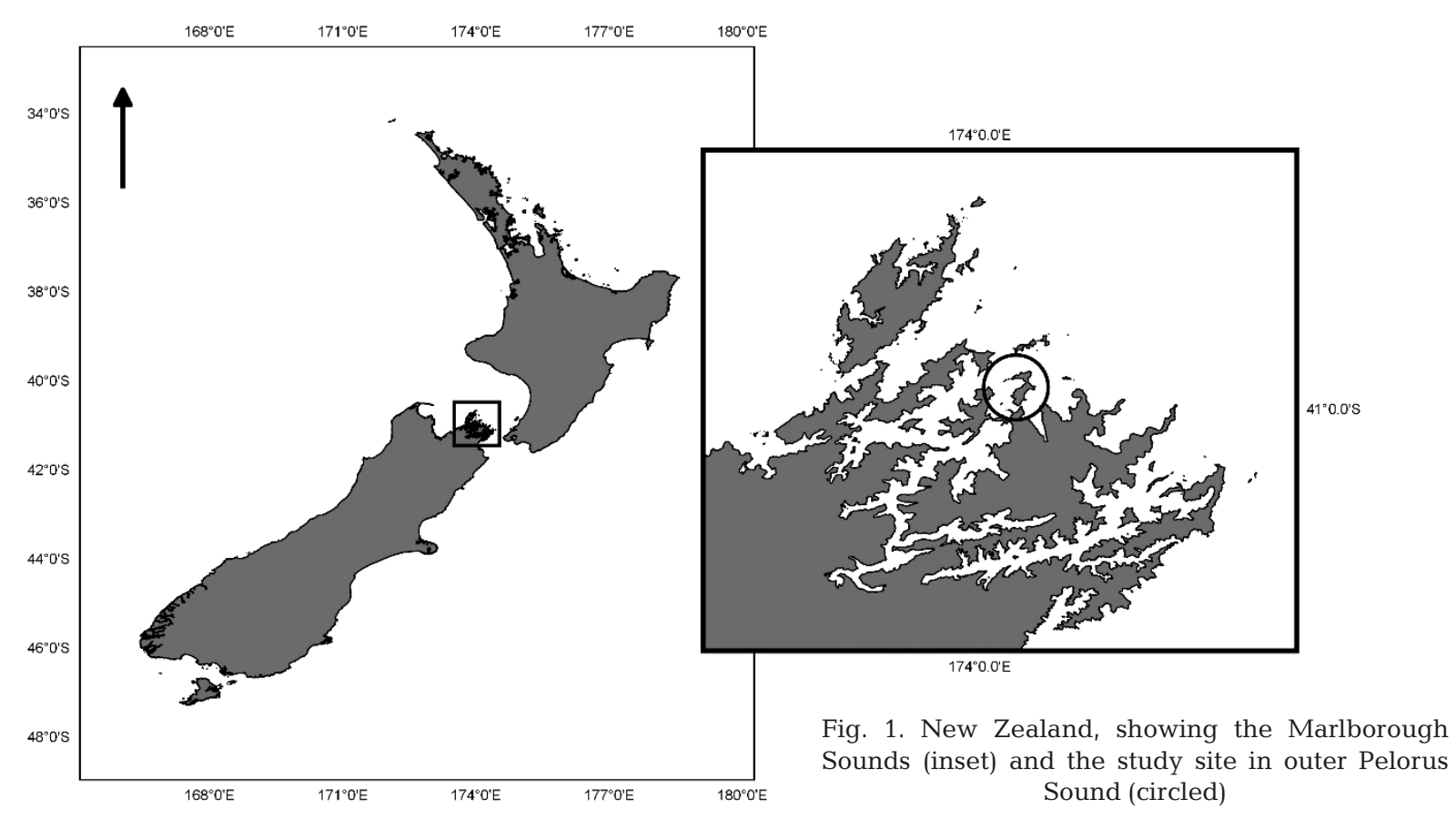


rentage, ad libitum access to food and managed densities, and are therefore less likely to show wide variation in their response to experimental conditions than are wild juveniles. In the hatchery, larval mussels were settled onto fibrous coir (coconut fibre ropes ca. $10 \mathrm{~mm}$ in diameter) ropes that are transported to the nursery site and deployed alongside a typical fibrous polypropylene nursery rope which is suspended in the water column from a buoyed surface line to form a nursery rope. The polypropylene rope and coir rope containing the juveniles are held together with a mesh sock placed over the 2 strands which collectively form a nursery rope. However, only the polypropylene rope is a permanent structure and the coir and sock degrade and are subsequently lost during production.

\section{Experimental design}

A field experiment was initiated on 13 October 2015 to test whether the presence of adult Perna canaliculus on nursery ropes would increase the retention of conspecific juvenile seed mussels. This experiment was deployed in October (i.e. early austral spring) because this is typically a period of low primary settlement of $P$. canaliculus at the study site and therefore our estimates of retention were less likely to be confounded by over-settling conspecifics early in the experimental period. At other times of the year, new cohorts are easy to determine using size and morphological characteristics (Redfearn et al. 1986, Atalah et al. 2016). Furthermore, the mussel farm used in this study was in $30 \mathrm{~m}$ deep water, with the experiment deployed at $4 \mathrm{~m}$ depth, while the secondary settlement by wild mussels typically occurs deeper in the water column (Alfaro \& Jeffs 2003).

Fifty experimental nursery ropes $(45 \mathrm{~cm}$ in length, hereafter 'experimental ropes') were assigned to 1 of 5 treatments that included 2 densities of live adult $P$. canaliculus (5 and 20 adults per experimental rope, hereafter PL $[P$. canaliculus Low] and PH $[P$. canaliculus High], respectively), 2 densities of empty adult shells that were included to examine the structural effects of adult mussels without their biological functioning such as defecation, byssus production and filter feeding ( 5 and 20 shells per experimental rope, hereafter SL [Shell Low] and SH [Shell High], respectively), and a control to which no adults or shells were added (hereafter, C). The high adult mussel and shell density of 20 rope $^{-1}$ (i.e. $44 \mathrm{~m}^{-1}$ ) was chosen to reflect typical densities of mussels of the size used in this experiment at cropping, in a com- mercial aquaculture setting. An additional 10 ropes were seeded and transported to the study site, but were not deployed, being retained for analyses to provide an estimate of the starting density on experimental ropes. The live adult mussels used in this experiment were obtained from a nearby mussel farm and were 93.1 $\pm 2.1 \mathrm{SE} \mathrm{mm}(\mathrm{n}=20)$ in shell length. Biofouling organisms were removed from the live adults, which were then deployed at even intervals along the experimental ropes to replicate a typical arrangement of adult mussels on a growing line. The rope and the mussels were then held together by covering with a mesh stocking. The adult mussel shells were $91.7 \pm 1.0 \mathrm{~mm}(\mathrm{n}=20)$ in shell length and were glued together to represent the physical form of adult mussels, and glued to the polypropylene rope at regular intervals. Similar amounts of glue were added to all of the other polypropylene ropes used in this experiment as a procedural control.

$P$. canaliculus are grown in a longline culture system that comprises continuous looped ropes suspended from 2 buoyed longlines (Jeffs et al. 1999, Woods et al. 2012). Each buoy is 6-8 $\mathrm{m}$ apart, forming 'bays' between buoys from which the nursery and the later grow-out ropes are hung. The present experiment occupied 1 such bay made available on a commercial mussel farm and involved the deployment of 5 rectangular frames $(100 \times 90 \mathrm{~cm})$ consisting of 2 wooden vertical rods $(20 \times 10 \times 900 \mathrm{~mm})$ intersected horizontally at the top, middle and bottom by 3 cylindrical nylon rods $(10 \times 1000 \mathrm{~mm}$; Fig. 2$)$. The frames were lashed at $1 \mathrm{~m}$ intervals to the backbone lines and hung at a depth of $4 \mathrm{~m}$. The frames were weighted in order to align them vertically in the water column. Two replicates of each experimental treatment were cable-tied to each of the frames (Fig. 2). These experimental ropes were positioned in a random order, $\sim 15 \mathrm{~cm}$ apart on the frame and sat vertically in the water column to reflect the typical position of a commercial mussel aquaculture nursery rope used for rearing juvenile mussels of this species. Each experimental rope was seeded with $45 \mathrm{~cm}$ length of coir rope coated in hatchery-raised juveniles that were seeded according to standard industry practices. The hatchery-raised juveniles were approximately $6 \mathrm{wk}$ post-settlement, and their shell length ranged from 0.29 to $1.76 \mathrm{~mm}$ with a mean length of $1.01 \mathrm{~mm} \pm 0.01(\mathrm{n}=498)$. All of the experimental ropes were transported to the study site in a cool and damp environment to reduce the likelihood of mortality or modified secondary settlement behaviour as artefacts of factors occurring during transport (Carton et al. 2007). 


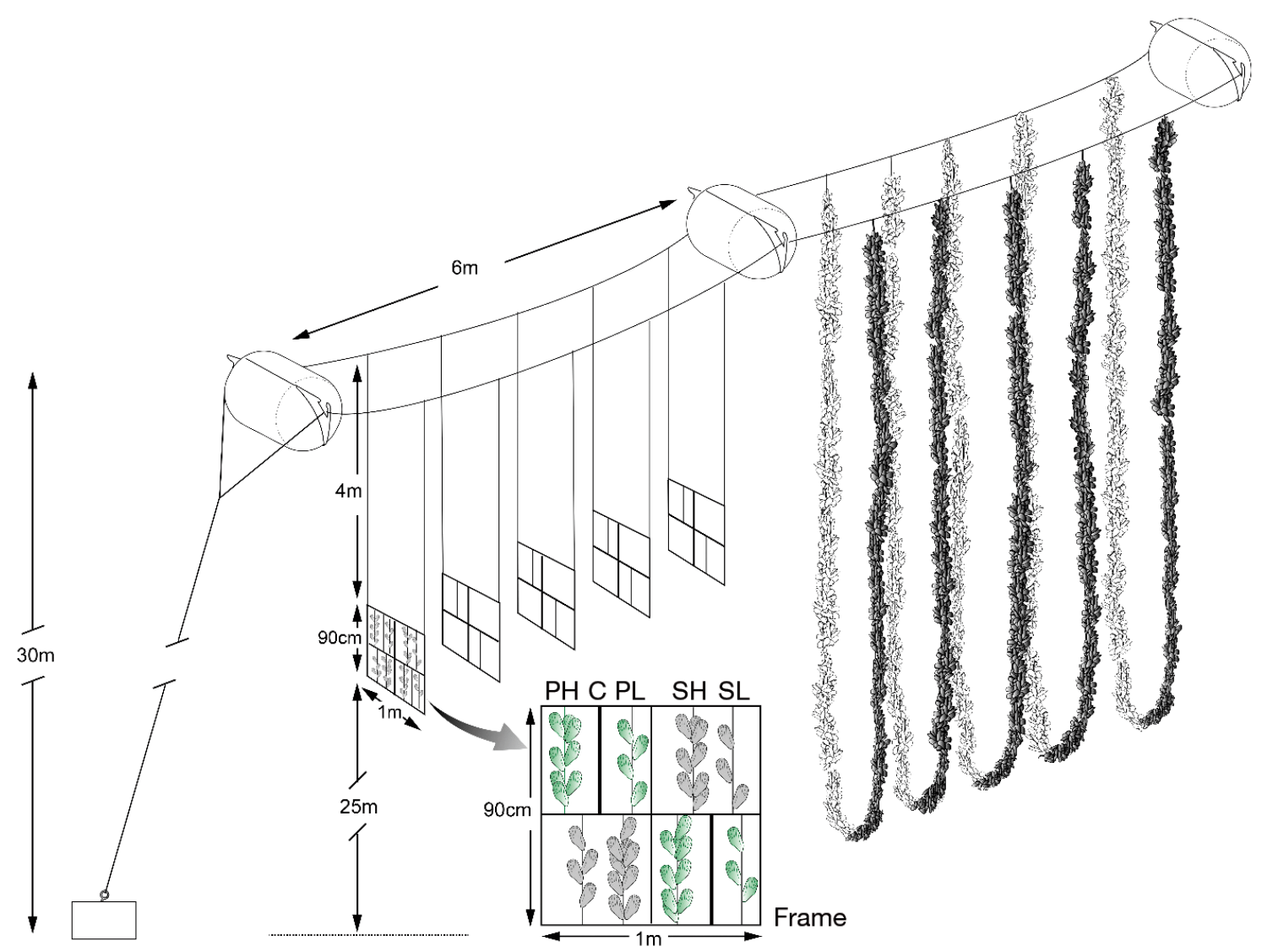

Fig. 2. Experimental set-up on a long-line culture system at the study site in outer Pelorus Sound. Frames were $1 \mathrm{~m}$ apart. The inset depicts the spatial arrangement of replicates on the frames. The treatments were a control with no mussels added to experimental ropes $\left(\mathrm{C}_{i}\right.$ thick black line) and experimental ropes with low or high densities of either live adult Perna canaliculus (Perna Low [PL] and Perna High [PH], green mussels) or their shells (Shells Low [SL] and Shells High [SH], grey mussels). Ex-

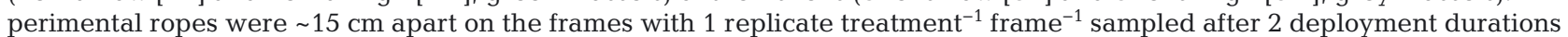
(1 and $5 \mathrm{mo})$

After $30 \mathrm{~d}$ (hereafter, $1 \mathrm{mo}$ ), 1 experimental rope from each treatment from each frame was randomly collected by removing the frames from the water and cutting the cable ties. Sampling was repeated at the conclusion of the experiment after $145 \mathrm{~d}$ (hereafter, $5 \mathrm{mo}$ ). At each sampling, 5 experimental ropes per treatment were collected. Experimental ropes were returned to the laboratory and separated into the 3 substrata (coir, polypropylene rope and socks). Large biofouling organisms were removed with tweezers, and each substratum was then washed over a $250 \mu \mathrm{m}$ sieve to ensure any wild primary mussel settlers were also captured. Experimental substrata were checked after washing to ensure that all juvenile mussels were sampled. The numbers of juvenile $P$. canaliculus within each substratum were counted, and 50 individuals were measured from each experimental rope using image analysis (to $0.01 \mathrm{~mm}$ precision) and Vernier callipers (to $0.5 \mathrm{~mm}$ precision) at 1 and $5 \mathrm{mo}$, respectively. The shell length of 20 randomly selected Myti- lus galloprovincialis that arrived on each experimental rope were measured for the experimental ropes that were sampled at $1 \mathrm{mo}$. All biofouling organisms (>1 mm) were identified to the highest possible taxonomic resolution (usually to family level or higher) and counted. The dry weights (after $48 \mathrm{~h}$ at $50^{\circ} \mathrm{C}$ ) of biofouling algae and sessile invertebrates were quantified. All settlers of $P$. canaliculus (assessed by smaller size than hatchery juveniles), M. galloprovincialis and Modiolarca impacta $>250 \mu \mathrm{m}$ on the experimental ropes were identified and counted.

\section{Statistical analyses}

Variation among experimental factors for all analyses in this study was tested using permutational analysis of variance (PERMANOVA), which has no assumption of data normality, but assumes homogeneity of variances (Anderson et al. 2008). Coch- 
ran's $C$-test was used to assess the variance structure of data used for each univariate analysis. Where there was significant heterogeneity, data were transformed (square root, $\log [x+1]$ or arcsine-square root) to stabilise variances. When transformation failed to homogenise the data, the results from analysed data were considered significant only at $p<0.01$ to decrease the risk of Type 1 error. For multivariate tests, the PERMDISP routine was used to assess data dispersion. PERMANOVA was used to analyse univariate and multivariate data using distance matrices based on Euclidean distances and Bray Curtis similarities, respectively. Non-metric multidimensional scaling (nMDS) was used to visualise differences in biofouling assemblage composition prior to multivariate tests. Pairwise comparisons were used to determine between-treatment differences for significant effects in the full models. Tests were based on 999 (size data) or 9999 (all other data) permutations.

\section{Retention of juvenile mussels}

The effect of Duration $(0,1$ and 5 mo) on the number of juvenile mussels was tested with a PERMANOVA using only the untreated control experimental ropes in order to determine patterns of retention on typical aquaculture substrata.

\section{Effects of adult mussels on juvenile retention, distribution and size}

The planned analysis included the factors Treatment (C, SL, SH, PL and PH), Substratum (coir, polypropylene rope and sock) and Duration (1 mo, $5 \mathrm{mo}$ ). However, separating the substrata turned out to be impossible after 5 mo due to the interwoven biofouling and mussel byssus. Therefore, the number of juveniles retained was summed across substrata for each experimental rope to test for the effects of Treatment and Duration on juvenile retention using a PERMANOVA model with the factors Treatment (C, $\mathrm{SL}, \mathrm{SH}, \mathrm{PL}$ and $\mathrm{PH}$, fixed effect), Duration (1 and 5 mo, fixed) and Frame (1-5, random). Where Frame was used as a factor in the analysis, variation due to the highest-order interaction could not be calculated due to insufficient replication and was assumed to be a component of the residual variation (Anderson et al. 2008). Therefore, factors are tested for the presence of main effects over and above interactions involving frames (Quinn \& Keough 2002), with the caveat that the significance of main effects might not be spatially consistent. A separate PERMANOVA was undertaken using only the 1 mo data to examine the distribution of juveniles on the 3 substrata, thereby assessing small-scale migrations (i.e. the number of juvniles that had moved from coir to the other substrata). The factors Treatment (C, SL, SH, PL and PH) and Substratum (coir, polypropylene rope and sock) were fixed while Frame (1-5) was a random factor. Additional separate analyses were done for each individual substratum (coir, polypropylene rope and sock) after 1 mo to test the effects of Treatment (fixed) and Frame (random) on the percentage of the total number of juveniles on each experimental rope. Finally, the size of the juvenile $P$. canaliculus was analysed separately at 1 and 5 mo for the effects of Treatment (fixed) and Frame (random). Size frequency distributions for each of the durations $(0,1$ and $5 \mathrm{mo})$ were inspected to determine whether any natural settlement of $P$. canaliculus was present. Data are presented as means $\pm \mathrm{SE}$, unless stated otherwise.

\section{Effects of adult mussels on the recruitment of biofouling organisms}

Data for the 6 most abundant taxa, the total biomass of sessile invertebrates and algae and the entire biofouling assemblage (multivariate data were fourthroot transformed) were pooled across substrata to test for the effects of Treatment $(\mathrm{C}, \mathrm{SL}, \mathrm{SH}, \mathrm{PL}$ and $\mathrm{PH}$, fixed), Duration (1 and 5 mo, fixed) and Frame (1-5, random). The similarity of percentages (SIMPER) routine was used to determine the proportional contribution of individual biofouling taxa to variation among treatments for multivariate data. To test whether the most abundant biofoulers after 1 mo were distributed differentially among substrata, the factors Treatment (C, SL, SH, PL and PH, fixed), Substrata (coir, polypropylene rope and sock, fixed) and Frame (1-5, random) were analysed with PERMANOVA.

After 5 mo, many of the adult mussels had been lost from the experimental ropes. Therefore, correlation analyses (Pearson's product moment) were used across live mussel treatments (i.e. PL and $\mathrm{PH}$ ) to determine whether the number of remaining adults might be associated with the magnitude of biofouling development. The number or biomass of common biofouling taxa was correlated (Pearson's product moment on $\log [x+1]$ transformed data) to the number of juvenile $P$. canaliculus after $1 \mathrm{mo}$ and $5 \mathrm{mo}$ separately to determine whether biofouling may be implicated in juvenile losses. Correlation analyses were done across experimental mussel treatments. 
Analyses were done in PRIMER 6 \& PERMANOVA+ (PRIMER-E) and STATISTICA 12 (StatSoft).

\section{RESULTS}

\section{Retention of juvenile mussels}

At the beginning of the experiment, $787.5 \pm 20.4$ (mean $\pm \mathrm{SE}, \mathrm{n}=10$ ) juvenile Perna canaliculus were attached to the experimental ropes. Considerable reductions in the abundance of juvenile mussels were observed on the untreated control ropes after 1 mo (decreasing to $422.4 \pm 61.1$ mussels, i.e. $46.4 \%$ less) and then again after 5 mo (145.6 \pm 10.2 mussels), resulting in a significant effect of Duration $\left(F_{2,12}=\right.$ 65.7, p $<0.001$, Table 1 ) in the analysis. On average, retention of juveniles after 5 mo was $18.5 \%$ (i.e. an $81.5 \%$ loss relative to initial abundance).

\section{Effects of adult mussels on juvenile retention, distribution and size}

After $1 \mathrm{mo}$, all of the live adult mussels added to the experimental treatments (i.e. PL, PH) had attached to the polypropylene rope, survived and remained. Despite being spread out along the polypropylene rope on deployment, the adult mussels moved along the ropes to form clumps, and generally all adults on individual experimental ropes were attached to one another. Several vacant patches of adult mussel byssus on the ropes suggested that adults had attached and subsequently moved on multiple occasions during this first month. After $5 \mathrm{mo}$, the number of adult mussels remaining ranged from 0 to $18(0,0$, $8,16,18)$ in the $\mathrm{PH}$ and 2 to $5(2,3,4,5,5)$ in PL treat-

Table 1. PERMANOVA testing for the effects of deployment duration $(0,1$ and $5 \mathrm{mo})$ on the number of juvenile Perna canaliculus retained on experimental ropes. f/r: fixed/random. Bold text indicates significance at $\mathrm{p}<0.05$. Perms: number of unique permutations for each factor in the analysis

\begin{tabular}{|lcccccc|}
\hline Source & $\mathrm{f} / \mathrm{r}$ & $\mathrm{df}$ & $\mathrm{MS}$ & $F / t$ & $\mathrm{p}$ & Perms \\
\hline $\begin{array}{l}\text { Main test } \\
\text { Duration }\end{array}$ & $\mathrm{f}$ & 2 & $\mathbf{4 . 6 0 8}$ & $\mathbf{6 5 . 7 2 1}$ & $\mathbf{0 . 0 0 0 1}$ & $\mathbf{9 9 5 2}$ \\
Residual & & 17 & 7.011 & & & \\
Pairwise $t$-tests & & & & & \\
$0>1$ & & & & $\mathbf{3 . 5 6 7}$ & $\mathbf{0 . 0 0 2}$ & $\mathbf{2 8 5 5}$ \\
$0>5$ & & & & $\mathbf{6 . 8 4 4}$ & $\mathbf{0 . 0 0 0 5}$ & $\mathbf{2 2 2 8}$ \\
$1>5$ & & & & $\mathbf{4 . 4 6 7}$ & $\mathbf{0 . 0 0 7 2}$ & $\mathbf{9 1}$ \\
\hline
\end{tabular}

ments. However, there was no correlation between the number of remaining adult mussels and the number of juveniles on the experimental ropes (Pearson's $\mathrm{r}=0.31, \mathrm{p}=0.38$ ). Additionally, 2 live adult mussels were found on 1 of both the $\mathrm{C}$ and $\mathrm{SH}$ experimental ropes, after presumably having byssus-walked around the frame. All mussel shells (SL and SH treatments) remained at the end of the experiment. It was not possible to separate the different substrata from the experimental ropes after 5 mo in any of the treatments because the remaining coir and sock were tightly bound to the polypropylene rope with byssus from the juveniles and fouling by blue mussels Mytilus galloprovincialis.

The presence of live adult mussels or mussels shells, whether at high or low density on experimental ropes, had no effect on the retention of juvenile $P$. canaliculus (Treatment $F_{4,16}=1.8, \mathrm{p}=0.169$; Table 2, Fig. 3). Among the 5 treatments, the number of juvenile mussels declined between 1 and 5 mo (Duration $F_{4,16}=98.83, \mathrm{p}<0.01$; Fig. 3, Table 2). On average, all treatments had less than $25 \%$ of the original starting abundance of juvenile mussels at the end of the experiment.

One month following deployment of the experimental ropes, there were differences in small-scale migrations (i.e. juveniles that had moved from coir to ropes or outer socks) of juvenile mussels among the 3 substrata for the 5 treatments (Treatment $\times$ Substratum, $F_{8,56}=3.1, \mathrm{p}<0.01$, Table 3 ), with greater numbers of juveniles found on the polypropylene rope in $\mathrm{PH}$ (64.6 \pm 8.7) than in $\mathrm{SH}(25.2 \pm 7.4)$, SL $(25.0 \pm 5.7)$ and PL $(43.6 \pm 6.8)$ treatments (pairwise $t$-tests $\mathrm{p}<0.05)$.

The majority ( $>66 \%$ in all treatments) of the juvenile seed mussels remaining at 1 mo were still attached to the coir, and there were no differences among treatments (Treatment $F_{4,16}=1.82, \mathrm{p}=0.17$, Fig. $4 \mathrm{a}$, Table 4$)$. A greater percentage $(>10 \%)$ of

Table 2. PERMANOVA testing for the effects of seeding live adult mussels or their shells and deployment duration (1 and $5 \mathrm{mo}$ ) on the number of juvenile Perna canaliculus remaining on experimental ropes. $\mathrm{f} / \mathrm{r}$ : fixed/random. Bold text indicates significance at $\mathrm{p}<0.05$. Refer to Table 1 for 'Perms'

\begin{tabular}{|lcccccc|}
\hline Source & $\mathrm{f} / \mathrm{r}$ & $\mathrm{df}$ & $\mathrm{MS}$ & $F$ & $\mathrm{p}$ & Perms \\
\hline Treatment (T) & $\mathrm{f}$ & 4 & 0.22 & 1.85 & 0.169 & 9948 \\
Duration (D) & $\mathrm{f}$ & 1 & $\mathbf{1 0 . 1 1}$ & $\mathbf{9 8 . 8 3 5}$ & $\mathbf{0 . 0 0 8}$ & $\mathbf{5 2 6 4}$ \\
Frame (F) & $\mathrm{r}$ & 4 & 0.05 & 0.70 & 0.602 & 9946 \\
$\mathrm{~T} \times \mathrm{D}$ & $\mathrm{f}$ & 4 & 0.05 & 0.66 & 0.636 & 9956 \\
$\mathrm{~T} \times \mathrm{F}$ & $\mathrm{r}$ & 16 & 0.12 & 1.68 & 0.151 & 9943 \\
$\mathrm{D} \times \mathrm{F}$ & $\mathrm{r}$ & 4 & 0.1 & 1.41 & 0.269 & 9953 \\
Residual & & 16 & 0.07 & & & \\
\hline
\end{tabular}




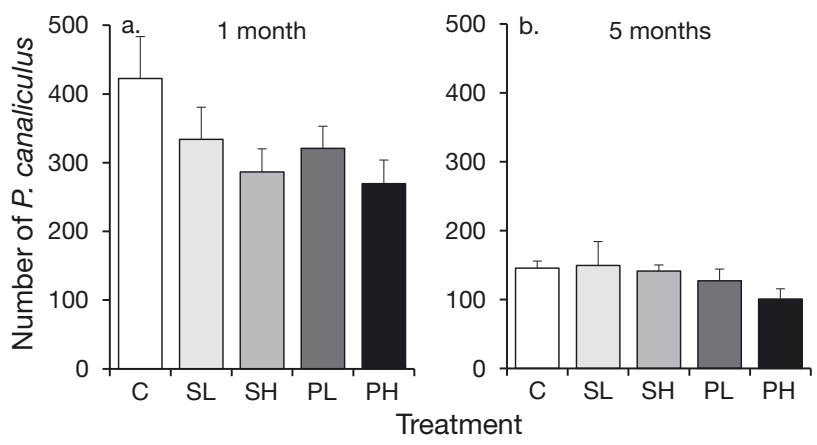

Fig. 3. Effects of the factors Treatment and Duration of deployment on the mean $( \pm$ SE) number of juvenile Perna canaliculus remaining on $45 \mathrm{~cm}$ experimental ropes at (a) $1 \mathrm{mo}$ and (b) 5 mo. C: control (0 adult mussels or shells), SL: shells at low density (5 empty $P$. canaliculus shells), SH: shells at high density (20 empty shells), PL: P. canaliculus at low density (5 live adults), and PH: P. canaliculus at high density (20 live adults)

juvenile mussels was found on the polypropylene rope in $\mathrm{PH}(24.1 \pm 1.6 \mathrm{SE})$ compared to all other treatments (Treatment $F_{4,16}=23.01, \mathrm{p}<0.0001$, Fig. 4 b, Table 4). There were no differences in the percent-

Table 3. PERMANOVA testing for the effects of seeding live adult mussels or their shells on the distribution of juvenile Perna canaliculus on aquaculture substrata after $1 \mathrm{mo} . \mathrm{f} / \mathrm{r}$ : fixed/random. Bold text indicates significance at $\mathrm{p}<0.05$. Refer to Table 1 for 'Perms'

\begin{tabular}{|lcccccc|}
\hline Source & f/r & df & MS & $F$ & $p$ & Perms \\
\hline Treatment (T) & f & 4 & 0.32 & 0.72 & 0.5947 & 9962 \\
Substratum (S) & f & 2 & $\mathbf{3 1 . 5 4}$ & $\mathbf{4 1 5 . 4 1}$ & $\mathbf{0 . 0 0 0 9}$ & $\mathbf{9 9 1 4}$ \\
Frame (F) & r & 4 & 0.18 & 1.66 & 0.1784 & 9941 \\
T $\times$ S & f & 8 & $\mathbf{0 . 6 2}$ & $\mathbf{5 . 8 1}$ & $\mathbf{0 . 0 0 0 4}$ & $\mathbf{9 9 5 5}$ \\
T $\times$ F & r & 16 & $\mathbf{0 . 4 4}$ & $\mathbf{4 . 1 1}$ & $\mathbf{0 . 0 0 0 2}$ & $\mathbf{9 9 2 4}$ \\
S $\times$ F & r & 8 & 0.08 & 0.71 & 0.6828 & 9941 \\
Residual & & 32 & 0.11 & & & \\
\hline
\end{tabular}
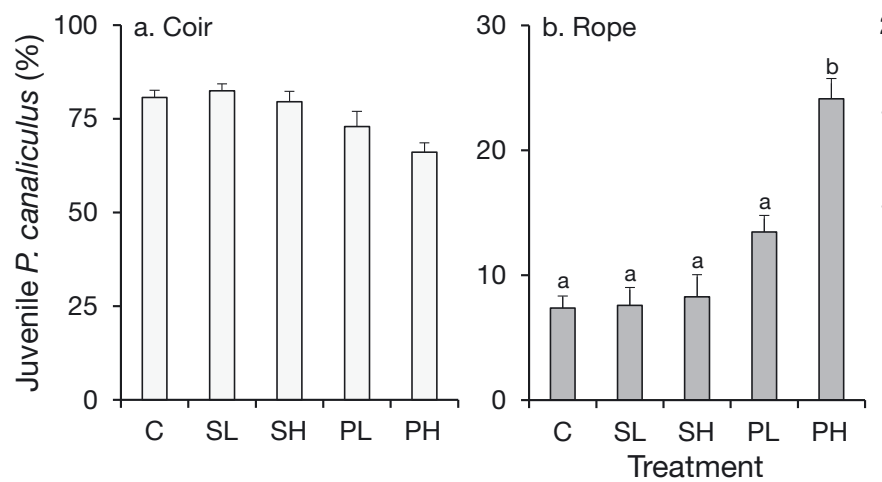

age of mussels attached to the socks among treatments (Treatment $F_{4,16}=0.49, \mathrm{p}<0.743$, Fig. 4c, Table 4). The number of $P$. canaliculus did not vary among experimental frames in any of the analyses undertaken.

One month following deployment, the juvenile $P$. canaliculus had attained an average size of $1.66 \pm$ $0.01 \mathrm{~mm}$ in length (range $=0.69-2.92 \mathrm{~mm}$ ), representing an average growth increment of $0.65 \mathrm{~mm}$. By $5 \mathrm{mo}$, the juveniles had grown to $20 \pm 0.004 \mathrm{~mm}$ (range $=6-36 \mathrm{~mm}$ ). However, at both deployment periods, the size of juveniles varied among frames $\left(1 \mathrm{mo}\right.$; Treatment $\times$ Frame $F_{16,1225}=2.09, \mathrm{p}<0.01$, 5 mo $F_{16,1225}=2.2, \mathrm{p}<0.01$, Fig. 5, Table 5), but no clear patterns among treatments emerged from post hoc analyses (Fig. 5). Mussels smaller than experimental cohorts were not observed throughout the experiment, indicating that there was an absence of primary settlement of $P$. canaliculus.

Table 4. PERMANOVA testing for the effects of seeding live adult mussels or their shells on the percentage of the remaining juvenile Perna canaliculus on aquaculture substrata after $1 \mathrm{mo}$. f/r: fixed/random. Bold text indicates significance at $\mathrm{p}<0.05$. Refer to Table 1 for 'Perms'

\begin{tabular}{|c|c|c|c|c|c|c|}
\hline Source & $\mathrm{f} / \mathrm{r}$ & df & MS & $F$ & $\mathrm{p}$ & Perms \\
\hline & & & \multicolumn{4}{|c|}{ Coir } \\
\hline Treatment & f & 4 & 12.74 & 0.49 & 0.7425 & 9952 \\
\hline Frame & $\mathrm{r}$ & 4 & 16.68 & 0.65 & 0.6453 & 9967 \\
\hline \multirow[t]{2}{*}{ Residual } & & 16 & 25.51 & & & \\
\hline & & & \multicolumn{4}{|c|}{ Rope } \\
\hline Treatment & f & 4 & 254.87 & 23.01 & 0.0002 & 9956 \\
\hline Frame & $\mathrm{r}$ & 4 & 7.95 & 0.71 & 0.5952 & 9959 \\
\hline \multirow[t]{2}{*}{ Residual } & & 16 & 11.07 & & & \\
\hline & & & \multicolumn{4}{|c|}{ Outer sock } \\
\hline Treatment & f & 4 & 12.74 & 0.49 & 0.7425 & 9964 \\
\hline Frame & $\mathrm{r}$ & 4 & 16.68 & 0.65 & 0.6453 & 9955 \\
\hline Residual & & 16 & 25.51 & & & \\
\hline
\end{tabular}

Fig. 4. Mean percentage ( \pm SE) of remaining juvenile Perna canaliculus on (a) coir, (b) polypropylene rope and (c) sock substrata among the 5 experimental treatments 1 mo after placement in the field. Treatment abbreviations as in Fig. 3. Lower case letters indicate significant differences between treatments. Note different scales on the $y$-axes 


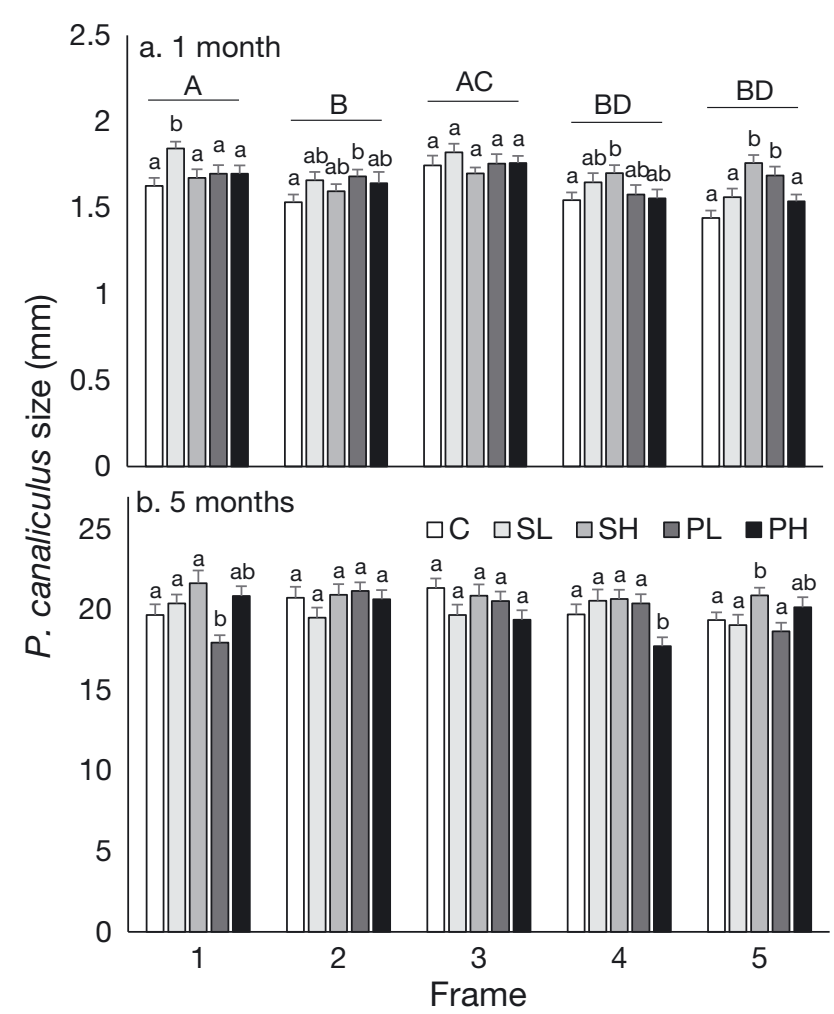

Fig. 5. Effects of the factors Treatment and Frame on the size (mean length + SE in mm) of Perna canaliculus at (a) 1 and (b) 5 mo. Treatment abbreviations as in Fig. 3. Lower case letters indicate significant differences between treatments following a significant Treatment $\times$ Frame interaction. Capitals indicate significant differences among frames where a main effect of Frame was observed. Note different scales on the $y$-axes

\section{Effects of adult mussels on the recruitment of biofouling organisms}

In this experiment, 68 biofouling taxa recruited to the experimental ropes, including amphipods, bivalves, ascidians, macroalgae and bryozoans. The 6 taxa that numerically dominated the biofouling assemblage were the mytilid mussels M. galloprovincialis and Modiolarca impacta and the amphipods
Ischyroceridae, Paradexamine spp., Caprella spp. and Parawaldeckia sp. There were significant negative correlations among the number of Caprella spp. $(\mathrm{r}=-0.5000, \mathrm{p}<0.05), M$. galloprovincialis $(\mathrm{r}=$ $-0.501, \mathrm{p}<0.05$ ) and $P$. canaliculus juveniles at $1 \mathrm{mo}$, but not at $5 \mathrm{mo}$.

The factor Duration (1 and $5 \mathrm{mo}$ ) explained the greatest amount of variation in the abundance of biofouling taxa (Fig. 6, Table 6). The abundance of Ischyroceridae, Paradexamine spp. and Caprella spp. decreased between 1 and 5 mo, while M. galloprovincialis, Parawaldeckia sp. and M. impacta increased in abundance. In addition, the biomass of sessile invertebrates and algae increased significantly between 1 and 5 mo.

Variation in the abundance of biofouling taxa among the treatments was more complex. The addition of shells $(\mathrm{SH})$ or live adult mussels $(\mathrm{PH})$ had significant positive effects on the number of $M$. galloprovincialis at 1 mo (Treatment $\times$ Duration, $F_{4,16}=6.41, \mathrm{p}<0.01$, Fig. 6a, Table 6) with the abundance of $M$. galloprovincialis in the $\mathrm{PH}(371.8 \pm 22.0 \mathrm{SE})$ treatment being greater (30.4-58.8\%) than in any other treatment (Fig. 6a). The SH $(258.0 \pm 14.8)$ treatment had significantly greater numbers of $M$. galloprovincialis than SL (199.8 \pm 21.5$)$ and C (153.2 \pm 18.1, Fig. 6a) at 1 mo. These $M$. galloprovincialis were between 0.25 and $1.5 \mathrm{~mm}$ in shell length, with a mean length of $0.81 \pm 0.01 \mathrm{~mm}$. There were no differences in the number of $M$. galloprovincialis among treatments at 5 mo (Fig. 6b), although there was a significant positive correlation between the number of $M$. galloprovincialis and the number of adult $P$. canaliculus remaining on the experimental ropes (Pearson's $\mathrm{r}=$ $0.78, \mathrm{p}=0.008)$.

There were greater numbers of the amphipods Ischyroceridae, Paradexamine spp. and Caprella spp. on $\mathrm{PH}$ compared to $\mathrm{C}$ treatments indicated by either significant main effects of Treatment (Table 6) or Treatment $\times$ Duration interactions (Fig. 6c-h, Table 6). For example, the tube-building amphipods Ischyro-

Table 5. PERMANOVAs testing for the effects of adding live mussels or their shells to aquaculture substrata on the size (length in $\mathrm{mm}$ ) of juvenile Perna canaliculus after 1 and $5 \mathrm{mo}$. f/r: fixed/random. Bold text indicates significance at $\mathrm{p}<0.05$. Refer to Table 1 for 'Perms'

\begin{tabular}{|c|c|c|c|c|c|c|c|c|c|c|}
\hline \multirow{2}{*}{ Source } & \multirow{2}{*}{$f / r$} & \multirow{2}{*}{ df } & \multicolumn{4}{|c|}{$-1 \mathrm{mo}$} & \multirow[b]{2}{*}{ MS } & \multicolumn{2}{|c|}{$-5 \mathrm{mo}$} & \multirow[b]{2}{*}{ Perms } \\
\hline & & & MS & $F$ & $\mathrm{p}$ & Perms & & $F$ & $\mathrm{p}$ & \\
\hline Treatment & $f$ & 4 & 0.018 & 2.738 & 0.074 & 999 & 0.029 & 1.277 & 0.315 & 999 \\
\hline Frame & $\mathrm{r}$ & 4 & 0.035 & 10.944 & 0.001 & 999 & 0.016 & 1.783 & 0.129 & 999 \\
\hline $\mathrm{T} \times \mathrm{F}$ & $\mathrm{r}$ & 16 & 0.007 & 2.090 & 0.007 & 998 & 0.023 & 2.492 & 0.002 & 999 \\
\hline Residual & & 1225 & 0.003 & & & & 0.009 & & & \\
\hline
\end{tabular}



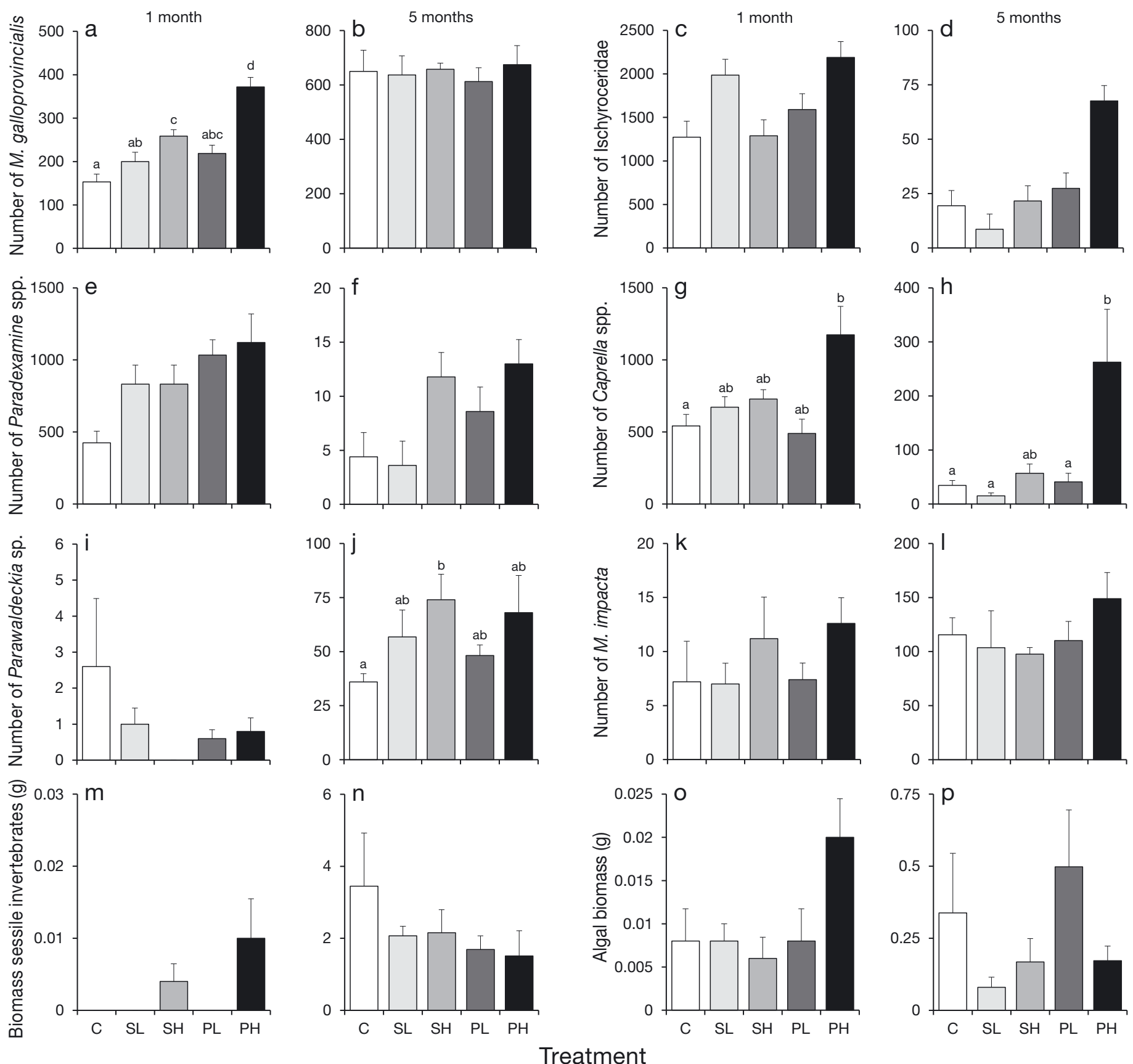

\section{Treatment}

Fig. 6. Effects of the factors Treatment and Duration (1 and $5 \mathrm{mo}$ ) on the mean (+ SE) abundance of the main biofouling organisms on the $45 \mathrm{~cm}$ experimental ropes. Treatment abbreviations as in Fig. 3. Different letters above bars indicate pairwise differences at $p<0.05$ for significant Treatment $\times$ Duration interactions. Pairwise results for significant main effects of Treatment are presented in Table 6. Duration was significant for all taxa $(\mathrm{p}<0.01)$. Note different scales on the $y$-axes

ceridae were significantly more abundant on $\mathrm{PH}$ compared to $\mathrm{C}, \mathrm{SL}$ and $\mathrm{SH}$ treatments (Treatment, $F_{4,16}$ 8.21, p < 0.001, Fig. 6c,d, Table 6) overall. By contrast, the amphipod Parawaldeckia sp. was more abundant on $\mathrm{SH}(74 \pm 11.24)$ compared to $\mathrm{C}(36 \pm 3.8)$ experimental ropes at 5 mo (Treatment $\times$ Duration, $F_{4,16}=$
4.19, $\mathrm{p}<0.05$; Fig. $6 \mathrm{i}, \mathrm{j}$, Table 6). There were no main or interactive effects of Treatment on the numbers of the bivalve M. impacta (Fig. 6k,l, Table 6) or the biomass of sessile invertebrates or algae (Fig. $6 \mathrm{~m}-\mathrm{p}$, Table 6). There were no effects of Frame in the analysis of count or biomass data for biofouling taxa. 


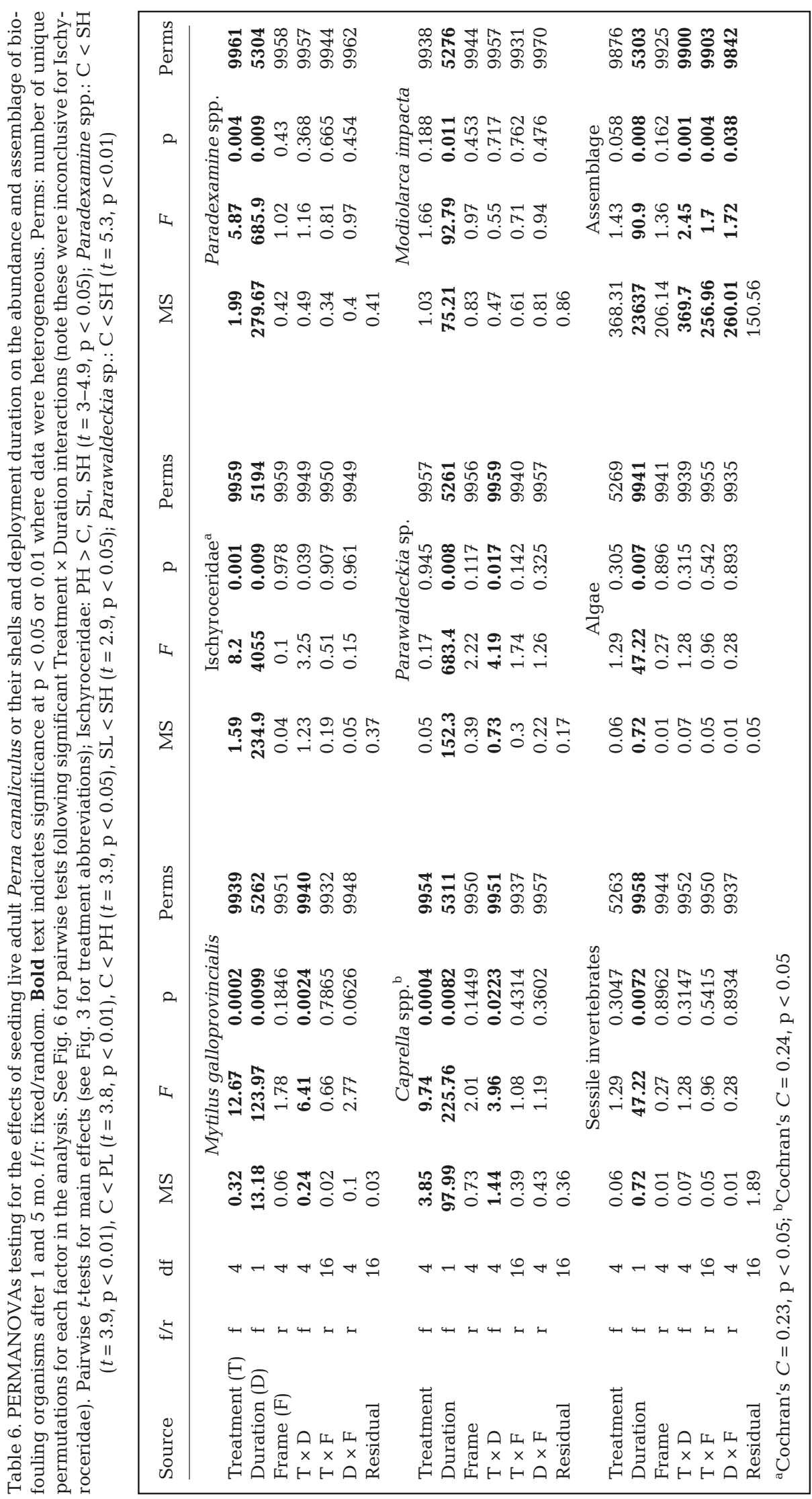

There were distinct differences in the composition of the biofouling assemblages on the experimental ropes between 1 and 5 mo (Duration, $F_{1,16}=90.91, \mathrm{p}<$ 0.01, Fig. 7a, Table 6). The biofouling assemblage on the $\mathrm{PH}$ treatment at $1 \mathrm{mo}$ varied from all other treatments except PL (Treatment $\times$ Duration, $F_{4,16}=2.45, \mathrm{p}<$ 0.01 , pairwise $t$-tests: $\mathrm{PH}$ different from $\mathrm{C}, \mathrm{SL}$ and $\mathrm{SH}, \mathrm{T}=1.94-2.35, \mathrm{p}<0.05$; Fig. $7 b)$. There were no differences in biofouling composition among treatments after 5 mo of immersion (pairwise $t$-tests: $t=0.724-$ 1.46, p > 0.12; Fig. 7c). Differences in assemblage composition among treatment or Duration levels were not always consistent among replicate frames (Treatment $\times$ Frame $, F_{16,16}=1.70, \mathrm{p}<$ 0.01 ; Duration $\times$ Frame, $F_{4,16}$ $=1.72, \mathrm{p}<0.01$, Table 6). Following the significant effect of Duration, SIMPER analysis indicated that there were greater numbers of Ischyroceridae, Paradexamine spp. and Caprella spp., and fewer $M$. impacta, Tanaidacea data not presented due to low overall relative abundance and $M$. galloprovincialis (accounting for $>50 \%$ of the dissimilarity) after 1 mo compared to $5 \mathrm{mo}$. After $1 \mathrm{mo}$, the taxa that contributed $>50 \%$ of the dissimilarity to amongtreatment differences (Ischyroceridae, Paradexamine spp., Caprella spp. and the masking crab Notomithrax minor, which was in low relative abundance) were in greater abundance in the $\mathrm{PH}$ treatment. 

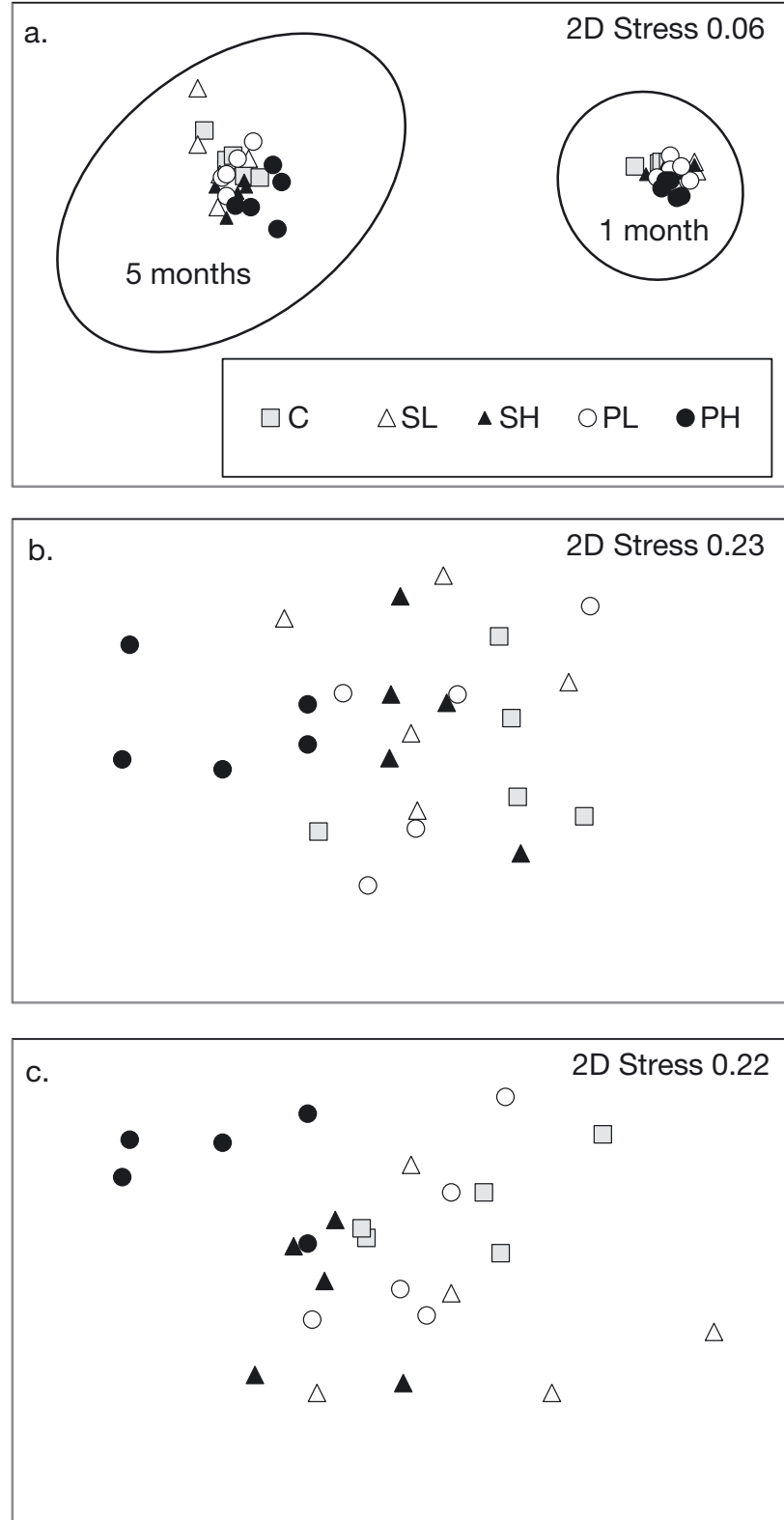

Fig. 7. Non-metric multidimensional scaling plot showing data dispersion in 5 treatments (a) across, (b) within 1 mo and (c) within 5 mo deployment durations. Replicates for each of 2 deployment durations ( 1 and $5 \mathrm{mo}$ ) are encircled in (a). Treatment abbreviations as in Fig. 3

\section{Distribution of biofouling organisms on aquaculture substrata}

At $1 \mathrm{mo}$, the most abundant biofouling organisms predominantly recruited to the sock and polypropylene rope (Fig. 8, Table 7). Greater numbers of M. galloprovincialis were found on the polypropylene rope in $\mathrm{PH}$ compared to all other treatments, and on the sock in PH compared to SL and C (Treatment $\times$ Substratum, $F_{8,32}=5.3, \mathrm{p}<0.001$, Fig. 8a, Table 7). Additionally, the $\mathrm{C}$ treatment had fewer $M$. galloprovincialis individuals than $\mathrm{SH}$ on the polypropylene rope, and $\mathrm{SH}$ and PL on the sock; there were no differences among treatments on the coir. There was also some spatial variability in the abundance of $M$. galloprovincialis (Treatment $\times$ Frame, $F_{16,32}=2.6, \mathrm{p}<0.05$, Table 7). At $1 \mathrm{mo}$, the number of Ischyroceridae was greater on the polypropylene rope substratum in SL compared to $\mathrm{C}$, and greater on the sock in $\mathrm{PH}$ compared to $\mathrm{C}$ treatments (Treatment $\times$ Substratum, $F_{8,16}=5.01, p<0.001$, Fig. 8b, Table 7). On the coir, there were significantly greater numbers of Ischyroceridae in C compared to SL, SH and PL treatments. Paradexamine spp. were more abundant on the polypropylene rope and sock than on the coir (Substratum, $F_{2,16}=33.0, \mathrm{p}<0.001$, Fig. 8c, Table 7), but did not vary in abundance among treatment levels. The number of Caprella spp. varied among the treatments on each of the substrata (Treatment $\times$ Substratum, $F_{8,16}=$ 6.7, p $<0.001$, Fig. 8d, Table 7), with more on the coir in $\mathrm{C}$ than all others, except $\mathrm{PH}$, and fewer on the sock in $\mathrm{C}$ compared to $\mathrm{PH}$ treatments. There were greater numbers of Caprella spp. on the rope in PH compared to SL treatments.

\section{DISCUSSION}

The results of this study demonstrate that high losses of juvenile Perna canaliculus from nursery ropes can be experienced early in commercial aquaculture production. On average $46 \%$ of the $P$. canaliculus juveniles were lost from experimental ropes after only 1 mo (average of 85.2 lost mussels rope $^{-1} \mathrm{wk}^{-1}$ ) and fewer than $19 \%$ of juvenile mussels remained after 5 mo (average of 13.4 lost mussels rope $^{-1} \mathrm{wk}^{-1}$ ). These data support earlier estimates of loss and suggest that understanding the causes of losses and mitigating against them would be beneficial to mussel production in New Zealand (Jeffs et al. 1999, Hayden \& Woods 2011). Including live adult mussels, or their shells, at 2 different densities had no effect on the retention of juvenile mussels over 1 and 5 mo under conditions typical of the early production cycle. Therefore, adult $P$. canaliculus did not mitigate stressors or suppress secondary settlement behaviour in juvenile mussels. Furthermore, many of the adult mussels were themselves lost when they were deployed at high density, providing additional evidence against the usefulness of simultaneous deployments of adults and juveniles. However, the addition of live 

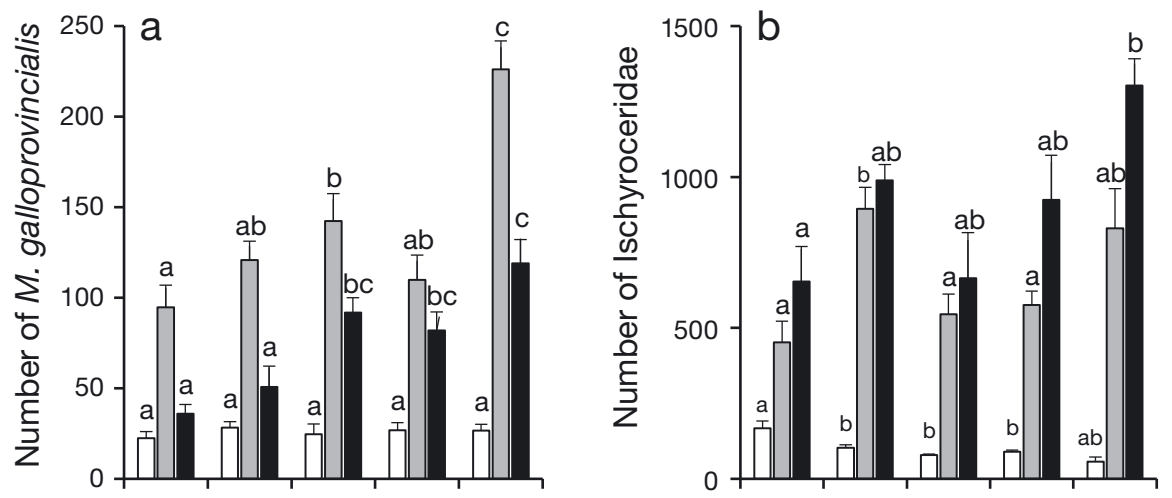

Fig. 8. Mean (+ SE) number of (a) Mytilus galloprovincialis, (b) Ischyroceridae, (c) Paradexamine spp. and (d) Caprella spp. on the coir (white bars), polypropylene rope (grey bars) and sock (black bars) among treatment after $1 \mathrm{mo}$ in the field. Treatment abbreviations as in Fig. $3 ; \mathrm{n}=5$ ropes treatment $^{-1}$, all experimental ropes were $45 \mathrm{~cm}$ in length. Different letters above bars indicate significant differences among treatments within substrata following a significant Treatment $\times$ Substratum interaction. Note different scales on the $y$-axes
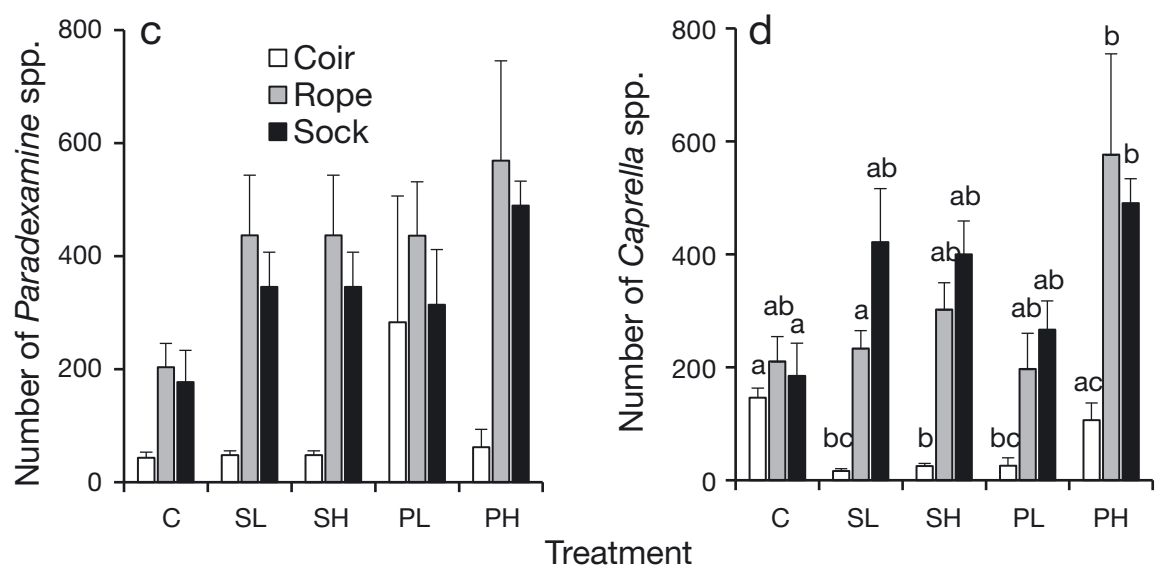

adult mussels or adult mussel shells did increase the abundance of some common biofouling organisms, in particular Mytilus galloprovincialis, which may have detrimental effects on mussel production (Fitridge et al. 2012, Sievers et al. 2013, Lacoste \& GaertnerMazouni 2015, Forrest \& Atalah 2017).

Secondary settlement behaviour is one likely cause of the observed losses of juvenile P. canaliculus (Jeffs et al. 1999, Hayden \& Woods 2011). Juvenile $P$. canaliculus of the same size as the juveniles used in our study have been observed to settle into natural habitats, indicating that juveniles of this size range readily use secondary settlement behaviour to change location (Buchanan \& Babcock 1997, Alfaro \& Jeffs 2003, Alfaro 2006b, South 2016). For example, pulses of settlement of $P$. canaliculus sized $>500 \mu \mathrm{m}$ were observed on collectors deployed for periods of only $1 \mathrm{~d}$ at a time on a rocky shore in southern New Zealand (South 2016). In northern New Zealand, settlers arriving at an intertidal mussel bed were $>2 \mathrm{~mm}$ in length (Alfaro 2006b). Therefore, it appears that $P$. canaliculus juveniles of the size deployed in this study (mean $=1.01 \pm 0.01 \mathrm{~mm}$ ) are highly mobile and could have migrated away from the experimental ropes. While it might be possible that juveniles could have migrated among experimental ropes in this study, it is highly unlikely, as there was no significant variation in juvenile numbers among treatments that would be consistent with such movements (Fig. 3).

Secondary settlement migration from the coir or algae on which mussels are initially seeded is essential to mussel production in New Zealand, because the coir and algae degrade over time, while the polypropylene rope offers a stable, permanent substratum. After $1 \mathrm{mo}$, a greater percentage $(\sim 10 \%)$ of juvenile mussels remaining on the experimental ropes had migrated from the coir to the polypropylene ropes when live adult mussels were added at the higher density. The underlying triggers of secondary settlement are not clear and could occur due to external factors such as chemical cues, changes in abiotic conditions or developmental changes in the juveniles. Alternatively, secondary settlement might be a response to negative changes in the immediate local environment, such as the recruitment of predatory species or organisms that modify food availability to the juveniles. It is possible that movements by the live adults along the nursery ropes could have displaced juveniles, causing them to re-locate onto the polypropylene rope. Juveniles might also have actively migrated away from adults, as a response to their biological functioning (defecation, byssus pro- 
Table 7. PERMANOVAs testing for the effects of adding live adult Perna canaliculus or their shells on the distribution of key biofouling organisms within experimental ropes after $1 \mathrm{mo}$ in the field. f/r: fixed/random. Bold text indicates significance at $\mathrm{p}<0.05$ or 0.01 where data were heterogeneous. Refer to Table 1 for 'Perms'

\begin{tabular}{|c|c|c|c|c|c|c|c|c|c|c|}
\hline Source & $\mathrm{f} / \mathrm{r}$ & df & MS & $F$ & $\mathrm{p}$ & Perms & MS & $F$ & $\mathrm{p}$ & Perms \\
\hline & & \multicolumn{5}{|c|}{ Mytilus galloprovincialis } & \multicolumn{4}{|c|}{ Ischyroceridae $^{a}$} \\
\hline Treatment $(\mathrm{T})$ & $\mathrm{f}$ & 4 & 1.167 & 6.546 & 0.0028 & 9956 & 0.397 & 0.733 & 0.6043 & 9955 \\
\hline Substratum (S) & $\mathrm{f}$ & 2 & 17.127 & 68.953 & 0.0001 & 9953 & 39.887 & 106.31 & 0.0003 & 9939 \\
\hline Frame (F) & $\mathrm{r}$ & 4 & 0.029 & 0.414 & 0.7986 & 9953 & 0.228 & 0.912 & 0.4788 & 9949 \\
\hline $\mathrm{T} \times \mathrm{S}$ & $\mathrm{f}$ & 8 & 0.365 & 5.3 & 0.0004 & 9956 & 1.255 & 5.013 & 0.0003 & 9940 \\
\hline $\mathrm{T} \times \mathrm{F}$ & $\mathrm{r}$ & 16 & 0.178 & 2.591 & 0.0106 & 9941 & 0.542 & 2.164 & 0.0192 & 9918 \\
\hline $\mathrm{S} \times \mathrm{F}$ & $\mathrm{r}$ & 8 & 0.248 & 3.611 & 0.0039 & 9937 & 0.375 & 1.499 & 0.1826 & 9956 \\
\hline \multirow[t]{2}{*}{ Residual } & & 32 & 0.069 & & & & 0.25 & & & \\
\hline & & & \multicolumn{4}{|c|}{ Paradexamine spp. } & \multicolumn{4}{|c|}{ Caprella spp. ${ }^{\mathrm{b}}$} \\
\hline Treatment & $\mathrm{f}$ & 4 & 1.116 & 1.818 & 0.1712 & 9958 & 3.076 & 6.929 & 0.0017 & 9973 \\
\hline Substratum & $\mathrm{f}$ & 2 & 28.921 & 33.009 & 0.0009 & 9950 & 34.246 & 90.572 & 0.0006 & 9951 \\
\hline Frame & $\mathrm{r}$ & 4 & 0.991 & 1.41 & 0.245 & 9954 & 0.21 & 0.609 & 0.6642 & 9949 \\
\hline $\mathrm{T} \times \mathrm{S}$ & $\mathrm{f}$ & 8 & 0.889 & 1.264 & 0.2909 & 9948 & 2.315 & 6.701 & 0.0001 & 9947 \\
\hline $\mathrm{T} \times \mathrm{F}$ & $\mathrm{r}$ & 16 & 0.614 & 0.873 & 0.6102 & 9930 & 0.444 & 1.285 & 0.2602 & 9915 \\
\hline $\mathrm{S} \times \mathrm{F}$ & $\mathrm{r}$ & 8 & 0.876 & 1.246 & 0.3033 & 9944 & 0.378 & 1.095 & 0.3909 & 9938 \\
\hline Residual & & 32 & 0.703 & & & & 0.345 & & & \\
\hline
\end{tabular}

duction) or competition for food. Alternatively, juvenile mussels might have moved towards the adults that were mostly attached to the polypropylene rope (Porri et al. 2016). Movement of juveniles towards adults would provide support for the original hypothesis that adults might have some influence on the retention of juveniles, but the number of mussels undertaking such movements was insufficient to have any effect on the number of mussels retained during the course of this experiment. The addition of live adult mussels or mussel shells to the experimental ropes led to an increase in the abundance of biofouling organisms, and this, or the presence of the adults, may have prompted the relocation of the juvenile mussels.

The ability of $P$. canaliculus juveniles to mucusdrift to facilitate secondary settlement ends at around $6 \mathrm{~mm}$ in shell length, and this might explain the reduced rate of loss of juvenile mussels from the experimental ropes observed after 1 mo (Fig. 3 in the present study, Buchanan \& Babcock 1997). Losses of juvenile mussels from aquaculture substrata could also be due to other factors that include variations in genetics and fitness among individuals (Phillips 2002, Alcapán et al. 2007, Sim-Smith \& Jeffs 2011), disease (Jones et al. 1996), predation pressure (Hayden 1995, Peteiro et al. 2010), biofouling (Fitridge et al. 2014) and stressors associated with the relay of juveniles from the hatchery or wild collection sites to the nursery farm location that might increase mortality or trigger secondary settlement (Webb \& Heasman 2006, Carton et al. 2007). Quantifying the rela- tive importance of the causes of loss has not been satisfactorily achieved in this and other studies and remains an important research priority.

The addition of live adult mussels in high density to experimental ropes generally increased the abundance and composition of biofouling organisms after $1 \mathrm{mo}$ in the field. Adding low densities of live adults, or only the shells of adults, had weaker effects on biofouling development (Fig. 6). Together this indicates that factors such as increased habitat area, refuge from predation and abiotic stress, as well as modification of food availability that are associated with adult mussels in high density, might have been important for many of the biofouling taxa recorded in this study (Commito \& Rusignuolo 2000). Biofouling organisms can compete for food and space with cultured organisms, leading to reduced biomass and crop losses (Ramsay et al. 2008, De Nys \& Guenther 2009, Sievers et al. 2013). The increased abundance of biofouling organisms associated with the presence of adult mussels (alive or shells) did not appear to affect the retention of juveniles. For example, the number of $P$. canaliculus juveniles was not significantly smaller where live adults were added in high density and where biofoulers such as M. galloprovincialis and Caprella spp. were in greater abundance. However, there were significant negative correlations between the number of remaining juveniles and the number of Caprella spp. and M. galloprovincialis, at $1 \mathrm{mo}$, a trend that warrants further targeted research to determine possible effects of these species. 
M. galloprovincialis responded differentially to the presence of live adults versus shells after 1 mo (Fig. 6a). The number of M. galloprovincialis was more than double in the high live adult density treatment after 1 mo compared to the controls, clearly showing that experimental ropes bearing live mussels promote settlement or survival of M. galloprovincialis. Similar positive effects of adults on settlement have been reported in other studies of mytilid mussels (Nielsen \& Franz 1995, Dobretsov \& Wahl 2001, Sardiña et al. 2009, Dolmer \& Stenalt 2010). Adding mussel shells in high density also had a positive, albeit a smaller, effect on the number of $M$. galloprovincialis, indicating that this species may be benefitting from the structural properties of $P$. canaliculus shells (Dolmer \& Stenalt 2010). Given the small size $(0.25-1.5 \mathrm{~mm})$ of $M$. galloprovincialis settlers at $1 \mathrm{mo}$, it is likely that these arrived as primary settlers, although this experiment was not structured to test this. The greater number of $M$. galloprovincialis in treatments with live adult $P$. canaliculus could be the result of increased primary settlement due to chemical cues from the live adults (Alfaro et al. 2006) or the result of modified small-scale hydrodynamic patterns (Grizzle et al. 1996, Miron et al. 2000) and increased surface complexity associated with the adults (e.g. byssal threads) and shells (e.g. increased settlement area) (Cáceres-Martínez et al. 1994, Gribben et al. 2011). Alternatively, differences in the abundance of $M$. galloprovincialis among the treatments might have been due to variations in postsettlement processes such as mortality (Hunt \& Scheibling 1997, von der Meden et al. 2012), secondary settlement (von der Meden et al. 2010, South 2016) or predation (Hayden 1995, Peteiro et al. 2010). The positive effects of live adults and shells of $P$. canaliculus on the abundance of its congener M. galloprovincialis contrasts with the absence of any effect on the conspecific juveniles deployed on the experimental ropes. It is possible that adult-juvenile interactions are only important early in the settlement process or that M. galloprovincialis and P. canaliculus have different underlying settlement-recruitment strategies. The lack of primary settlement of $P$. canaliculus during this study did not allow for any comparison among treatments or with the settlement of M. galloprovincialis.

The strong increase in the number of $M$. galloprovincialis on experimental ropes bearing high densities of adult $P$. canaliculus has important implications for the New Zealand mussel industry and the surrounding natural environment (Rius et al. 2011). The blue mussel M. galloprovincialis has a wide global range with southern and northern lineages and is a successful invader of native ecosystems in many countries (McQuaid \& Phillips 2000, Braby \& Somero 2006, Branch et al. 2008, Gardner et al. 2016). In the Marlborough Sounds, M. galloprovincialis has increased in abundance over the last $25 \mathrm{yr}$ and has become a problematic biofouling organism that competes for food and displaces crops of $P$. canaliculus on growing lines (Woods et al. 2012, Atalah et al. 2017).

The most abundant biofouling taxa recruited differentially to the experimental substrata used to deploy seed mussels. For example, M. galloprovincialis settled heavily onto the polypropylene rope substratum (versus the socking or the coir), thereby occupying the space onto which $P$. canaliculus juveniles must migrate to remain in production. This result is in accordance with other studies that have shown M. galloprovincialis to have strong affinities for fibrous substrata such as the polypropylene ropes used in this study (Cáceres-Martínez et al. 1994, Carl et al. 2012). The amphipods Ischyroceridae built tubes constructed from fine sediment on the sock and polypropylene rope, potentially modifying smallscale hydrodynamic processes and food delivery to juvenile mussels (Fitridge et al. 2012), for which feeding is known to be limited due to rudimentary feeding structures (Gui et al. 2016). Critically, this suggests that the substrata used for mussel culture in New Zealand can promote the settlement of nuisance species and that more research is warranted to understand their impact and methods to deter them.

\section{CONCLUSIONS}

This study shows how high losses of seed mussels can greatly affect the efficiency of mussel production in a typical aquaculture setting in New Zealand. The majority of juvenile losses occurred within the first month, but continued over the following 5 mo. The addition of adult mussels to experimental ropes, while unsuccessful at increasing retention as originally hypothesised, provides considerable insight into how crops of mussels interact with their environment and the spatial and temporal dynamics of biofouling organisms in the early stages of aquaculture production. Overall, the presence of adult Perna canaliculus on experimental ropes increased the numbers of biofouling organisms subsequently arriving on these ropes, especially Mytilus galloprovincialis, most likely as a result of their provision of habitat and biological functioning. The polypropylene 
rope and outer sock substrata used by industry in nursery systems appear to promote the settlement of some biofouling organisms. Research into alternative systems is required to reduce the impacts of unwanted biofouling species on juvenile mussels in aquaculture.

Acknowledgements. We gratefully thank SpatNZ Ltd and in particular Dan McCall for providing juvenile Perna canaliculus, on-water support and aquaculture infrastructure for this project. Thanks to Fiona Gower and the taxonomy team at Cawthron Institute for their technical support. This research was funded by New Zealand Ministry of Business, Innovation and Employment under Contract CAWX1315 (The Cultured Shellfish Programme: Enabling, 447 Growing, and Securing NZ's Shellfish Aquaculture Sector). Vivien Ward kindly crafted Fig. 2. We thank 3 anonymous referees whose thoughtful and detailed critique greatly improved this work.

\section{LITERATURE CITED}

Alcapán AC, Nespolo RF, Toro JE (2007) Heritability of body size in the Chilean blue mussel (Mytilus chilensis Hupé 1854): effects of environment and ageing. Aquacult Res 38:313-320

Alfaro AC (2006a) Evidence of cannibalism and benthopelagic coupling within the life cycle of the mussel, Perna canaliculus. J Exp Mar Biol Ecol 329:206-217

Alfaro AC (2006b) Population dynamics of the green-lipped mussel, Perna canaliculus, at various spatial and temporal scales in northern New Zealand. J Exp Mar Biol Ecol 334:294-315

Alfaro AC (2006c) Byssal attachment of juvenile mussels, Perna canaliculus, affected by water motion and air bubbles. Aquaculture 255:357-361

Alfaro AC, Jeffs AG (2002) Small-scale mussel settlement patterns within morphologically distinct substrata at Ninety Mile Beach, northern New Zealand. Malacologia 44:1-15

Alfaro AC, Jeffs AG (2003) Variability in mussel settlement on suspended ropes placed at Ahipara Bay, Northland, New Zealand. Aquaculture 216:115-126

* Alfaro AC, Jeffs AG, Creese RG (2004) Bottom-drifting algal/ mussel spat associations along a sandy coastal region in northern New Zealand. Aquaculture 241:269-290

Alfaro AC, Copp BR, Appleton DR, Kelly S, Jeffs AG (2006) Chemical cues promote settlement in larvae of the green-lipped mussel, Perna canaliculus. Aquacult Int 14: 405-412

Alfaro AC, McArdle B, Jeffs AG (2010) Temporal patterns of arrival of beachcast green-lipped mussel (Perna canaliculus) spat harvested for aquaculture in New Zealand and its relationship with hydrodynamic and meteorological conditions. Aquaculture 302:208-218

Anderson MJ (1996) A chemical cue induces settlement of Sydney rock oysters, Saccostrea commercialis, in the laboratory and in the field. Biol Bull (Woods Hole) 190: 350-358

Anderson MJ, Gorley RN, Clarke KR (2008) PERMANOVA for PRIMER: guide to software and statistical methods. PRIMER-E, Plymouth
Aquaculture New Zealand (2016) Overview of New Zealand aquaculture. www.aquaculture.org.nz/industry/overview/ (accessed on 7 April 2016)

Atalah J, Rabel H, Forrest BM (2016) Blue mussel oversettlement predictive model and web application. Prepared for Marine Farming Association. Cawthron Report No. 2801. Cawthron Institute, Nelson

Atalah J, Rabel H, Forrest BM (2017) Modelling long-term recruitment patterns of blue mussels Mytilus galloprovincialis: a biofouling pest of green-lipped mussel aquaculture in New Zealand. Aquacult Environ Interact 9: 103-114

*Bayne BL (1964) Primary and secondary settlement in Mytilus edulis L. (Mollusca). J Anim Ecol 33:513-523

* Bertness MD, Grosholz E (1985) Population dynamics of the ribbed mussel, Geukensia demissa: the costs and benefits of an aggregated distribution. Oecologia 67:192-204

* Braby CE, Somero GN (2006) Ecological gradients and relative abundance of native (Mytilus trossulus) and invasive (Mytilus galloprovincialis) blue mussels in the California hybrid zone. Mar Biol 148:1249-1262

* Branch GM, Odendaal F, Robinson TB (2008) Long-term monitoring of the arrival, expansion and effects of the alien mussel Mytilus galloprovincialis relative to wave action. Mar Ecol Prog Ser 370:171-183

Buchanan S, Babcock R (1997) Primary and secondary settlement by the greenshell mussel Perna canaliculus. J Shellfish Res 16:71-76

* Cáceres-Martínez J, Robledo JAF, Figueras A (1994) Settlement and post-larvae behavior of Mytilus galloprovincialis: field and laboratory experiments. Mar Ecol Prog Ser 112:107-117

Capelle JJ, Wijsman JWM, Schellekens T, van Stralen MR, Herman PMJ, Smaal AC (2014) Spatial organisation and biomass development after relaying of mussel seed. J Sea Res 85:395-403

* Carl C, Poole AJ, Williams MR, de Nys R (2012) Where to settle-settlement preferences of Mytilus galloprovincialis and choice of habitat at a micro spatial scale. PLOS ONE 7:e52358

* Carrasco AV, Astorga M, Cisterna A, Farias A, Espinoza V, Uriarte I (2014) Pre-feasibility study for the installation of a Chilean mussel Mytilus chilensis (Hupe 1854) seed hatchery in the Lakes region, Chile. Fish Aquacult J 5: 102, doi:10.4172/2150-3508.1000102

Carton AG, Jeffs AG, Foote G, Palmer H, Bilton J (2007) Evaluation of methods for assessing the retention of seed mussels (Perna canaliculus) prior to seeding for growout. Aquaculture 262:521-527

Commito JA, Rusignuolo BR (2000) Structural complexity in mussel beds: the fractal geometry of surface topography. J Exp Mar Biol Ecol 255:133-152

De Nys R, Guenther J (2009) The impact and control of biofouling in marine finfish aquaculture. Woodshead Publishing, Cambridge

* de Vooys CGN (1999) Numbers of larvae and primary plantigrades of the mussel Mytilus edulis in the western Dutch Wadden Sea. J Sea Res 41:189-201

de Vooys CGN (2003) Effect of a tripeptide on the aggregational behaviour of the blue mussel Mytilus edulis. Mar Biol 142:1119-1123

*Dobretsov S, Wahl M (2001) Recruitment preferences of blue mussel spat (Mytilus edulis) for different substrata and microhabitats in the White Sea (Russia). Hydrobiologia 445:27-35 
Dolmer P, Stenalt E (2010) The impact of the adult blue mussel (Mytilus edulis) population on settling of conspecific larvae. Aquacult Int 18:3-17

Erlandsson J, Porri F, McQuaid CD (2008) Ontogenetic changes in small-scale movement by recruits of an exploited mussel: implications for the fate of larvae settling on algae. Mar Biol 153:365-373

FAO (Food and Agriculture Organization of the United Nations) (2016) The state of world fisheries and aquaculture 2016. Contributing to food security and nutrition for all. FAO, Rome

Fitridge I, Dempster T, Guenther J, de Nys R (2012) The impact and control of biofouling in marine aquaculture: a review. Biofouling 28:649-669

Fitridge I, Sievers M, Dempster T, Keough MJ (2014) Tackling a critical industry bottleneck: developing methods to avoid, prevent \& treat biofouling in mussel farms. Report No. CC BY 3.0. University of Melbourne

Forrest BM, Atalah J (2017) Significant impact from blue mussel Mytilus galloprovincialis biofouling on aquaculture production of green-lipped mussels in New Zealand. Aquacult Environ Interact 9:115-126

* Gardner JPA, Zbawicka M, Westfall KM, Wenne R (2016) Invasive blue mussels threaten regional scale genetic diversity in mainland and remote offshore locations: the need for baseline data and enhanced protection in the Southern Ocean. Glob Change Biol 22:3182-3195

* Gribben PE, Jeffs AG, de Nys R, Steinberg PD (2011) Relative importance of natural cues and substrate morphology for settlement of the New Zealand Greenshell ${ }^{\mathrm{TM}}$ mussel, Perna canaliculus. Aquaculture 319:240-246

* Grizzle RE, Short FT, Newell CR, Hoven H, Kindblom L (1996) Hydrodynamically induced synchronous waving of seagrasses: 'monami' and its possible effects on larval mussel settlement. J Exp Mar Biol Ecol 206:165-177

Gui Y, Zamora L, Dunphy B, Jeffs A (2016) Understanding the ontogenetic changes in particle processing of the greenshell ${ }^{\mathrm{TM}}$ mussel, Perna canaliculus, in order to improve hatchery feeding practices. Aquaculture 452: 120-127

Hayden BJ (1995) Factors affecting recruitment of farmed greenshell mussels, Perna canaliculus (Gmelin) 1791, in Marlborough Sounds. PhD thesis, University of Otago

Hayden BJ, Woods CMC (2011) Effect of water velocity on growth and retention of cultured Greenshell ${ }^{\mathrm{TM}}$ mussel spat, Perna canaliculus (Gmelin, 1791). Aquacult Int 19: 957-971

Holthuis TD, Bergström P, Lindegarth M, Lindegarth S (2015) Monitoring recruitment patterns of mussels and fouling tunicates in mariculture. J Shellfish Res 34: 1007-1018

*Hunt HL, Scheibling RE (1997) Role of early post-settlement mortality in recruitment of benthic marine invertebrates. Mar Ecol Prog Ser 155:269-301

Jeffs A, Holland R, Hooker S, Hayden B (1999) Overview and bibliography of research on the greenshell mussel, Perna canaliculus, from New Zealand waters. J Shellfish Res 18:347-360

Jones JB, Scotti PD, Dearing SC, Wesney B (1996) Virus-like particles associated with marine mussel mortalities in New Zealand. Dis Aquat Org 25:143-149

Lacoste E, Gaertner-Mazouni N (2015) Biofouling impact on production and ecosystem functioning: a review for bivalve aquaculture. Rev Aquacult 7:187-196

Lasiak TA, Barnard TCE (1995) Recruitment of the brown mussel Perna perna onto natural substrata: a refutation of the primary/secondary settlement hypothesis. Mar Ecol Prog Ser 120:147-153

* Le Corre N, Martel AL, Guichard F, Johnson LE (2013) Variation in recruitment: differentiating the roles of primary and secondary settlement of blue mussels Mytilus spp. Mar Ecol Prog Ser 481:133-146

McQuaid CD, Phillips TE (2000) Limited wind-driven dispersal of intertidal mussel larvae: in situ evidence from the plankton and the spread of the invasive species Mytilus galloprovincialis in South Africa. Mar Ecol Prog Ser 201:211-220

*Miron G, Walters LJ, Tremblay R, Bourget E (2000) Physiological condition and barnacle larval behavior: a preliminary look at the relationship between TAG/DNA ratio and larval substratum exploration in Balanus amphitrite. Mar Ecol Prog Ser 198:303-310

*Morello SL, Yund PO (2016) Response of competent blue mussel (Mytilus edulis) larvae to positive and negative settlement cues. J Exp Mar Biol Ecol 480:8-16

Naylor RL, Goldburg RJ, Primavera JH, Kautsky N and others (2000) Effect of aquaculture on world fish supplies. Nature 405:1017-1024

Newell CR, Short F, Hoven H, Healey L, Panchang V, Cheng G (2010) The dispersal dynamics of juvenile plantigrade mussels (Mytilus edulis L.) from eelgrass (Zostera marina) meadows in Maine, U.S.A. J Exp Mar Biol Ecol 394:45-52

Nielsen KJ, Franz DR (1995) The influence of adult conspecifics and shore level on recruitment of the ribbed mussel Geukensia demissa (Dillwyn). J Exp Mar Biol Ecol 188:89-98

*Pauly D, Christensen V, Guénette S, Pitcher TJ and others (2002) Towards sustainability in world fisheries. Nature 418:689-695

* Peteiro LG, Filgueira R, Labarta U, Fernández-Reiriz MJ (2007) Settlement and recruitment patterns of Mytilus galloprovincialis L. in the Ría de Ares-Betanzos (NW Spain) in the years 2004/2005. Aquacult Res 38:957-964

* Peteiro LG, Filgueira R, Labarta U, Fernández-Reiriz MJ (2010) The role of fish predation on recruitment of Mytilus galloprovincialis on different artificial mussel collectors. Aquacult Eng 42:25-30

*Phillips NE (2002) Effects of nutrition-mediated larval condition on juvenile performance in a marine mussel. Ecology 83:2562-2574

*Porri F, McQuaid CD, Erlandsson J (2016) The role of recruitment and behaviour in the formation of musseldominated assemblages: an ontogenetic and taxonomic perspective. Mar Biol 163:1-10

Quinn GP, Keough MJ (2002) Experimental design and data analysis for biologists. Cambridge University Press, Cambridge

Ramsay A, Davidson J, Landry T, Stryhn H (2008) The effect of mussel seed density on tunicate settlement and growth for the cultured mussel, Mytilus edulis. Aquaculture 275:194-200

* Redfearn P, Chanley P, Chanley M (1986) Larval shell development of four species of New Zealand mussels: (Bivalvia, Mytilacea). N Z J Mar Freshw Res 20:157-172

* Rius M, Heasman KG, McQuaid CD (2011) Long-term coexistence of non-indigenous species in aquaculture facilities. Mar Pollut Bull 62:2395-2403

* Sardiña P, Cataldo DH, Boltovskoy D (2009) Effects of conspecifics on settling juveniles of the invasive golden mussel, Limnoperna fortunei. Aquat Sci 71:479-486 
Sievers M, Fitridge I, Dempster T, Keough MJ (2013) Biofouling leads to reduced shell growth and flesh weight in the cultured mussel Mytilus galloprovincialis. Biofouling 29:97-107

Sim-Smith CJ, Jeffs AG (2011) A novel method for determining the nutritional condition of seed green-lipped mussels, Perna canaliculus. J Shellfish Res 30:7-11

Smaal A (2002) European mussel cultivation along the Atlantic coast: production status, problems and perspectives. Hydrobiologia 484:89-98

South PM (2016) An experimental assessment of measures of mussel settlement: effects of temporal, procedural and spatial variations. J Exp Mar Biol Ecol 482:64-74

Steinberg PD, de Nys R, Kjelleberg S (2002) Chemical cues for surface colonization. J Chem Ecol 28:1935-1951

von der Meden CEO, Porri F, McQuaid CD, Faulkner K,

Editorial responsibility: Philippe Archambault,

Rimouski, Québec, Canada
Robey J (2010) Fine-scale ontogenetic shifts in settlement behaviour of mussels: changing responses to biofilm and conspecific settler presence in Mytilus galloprovincialis and Perna perna. Mar Ecol Prog Ser 411: 161-171

* von der Meden CEO, Porri F, McQuaid CD (2012) New estimates of early post-settlement mortality for intertidal mussels show no relationship with meso-scale coastline topographic features. Mar Ecol Prog Ser 463:193-204

*Webb SC, Heasman KG (2006) Evaluation of fast green uptake as a simple fitness test for spat of Perna canaliculus (Gmelin, 1791). Aquaculture 252:305-316

* Woods CMC, Floerl O, Hayden BJ (2012) Biofouling on Greenshell ${ }^{\mathrm{TM}}$ mussel (Perna canaliculus) farms: a preliminary assessment and potential implications for sustainable aquaculture practices. Aquacult Int 20:537-557

Submitted: December 14, 2016; Accepted: May 30, 2017

Proofs received from author(s): July 17, 2017 